\title{
Grundtvig og den lutherske tradition
}

\section{Af Theodor Jørgensen}

Det er næppe uden bagtanke, at denne konferences arrangører har bedt både en kirkehistoriker og en systematisk teolog holde foredrag om dette emne. Jeg formoder, at man fra systematikerens side forventer en mere principiel vurdering af Grundtvigs forhold til lutherdommen, medens kirkehistorikeren skal tage sig af den historiske redegørelse. Det har jeg så holdt mig til. ${ }^{1}$

Jeg har selvsagt hæftet mig ved, at emneformuleringen er »Grundtvig og den lutherske tradition« og ikke »Grundtvig og Luther«. Det er jeg indforstået med. Det giver bedre mening både ud fra en historisk og en systematisk synsvinkel. Jeg har ganske vist selv tidligere behandlet emnet »Grundtvig og Luther «", men er blevet mere skeptisk over for det. Ud fra en historisk synsvinkel er det selvsagt berettiget at spørge om, hvad Grundtvig mente om Luther, og hvordan han fortolkede ham. Men allerede hvad Grundtvigs Luther-tolkning angår, kan det være vanskeligt for os at give en loyal vurdering af den. Det er med en vis ret blevet hævdet, at Luther i eftertiden først for alvor selv kom til orde i det 20. århundrede, selv om påstanden kan lyde lidt absurd. Men først i dette århundrede har vi fået den brede adgang til en hel række Luther-tekster, man ikke før havde kendskab til i samme omfang og i samme tekstmæssige kvalitet. Og først i dette århundrede har den historisk-kritiske omgang med Luther ført til, at man har kunnet frigøre ham fra den lutherskortodokse eftertids og sidenhen lutherdommens omklamring. Men det var i den omklamring, at Grundtvig mødte Luther, og Grundtvig evnede på bemærkelsesværdig måde ud fra sine forudsætninger også delvis at skære igennem denne omklamring. Når vi derimod i dag sammenligner Grundtvig og Luther, kommer vi til at gøre det på baggrund af vor tids nyopdagelse af Luther. Det er da heller ikke uinteressant, idet ligheder og forskelle henover tiderne kan tjene til at profilere både Luther og Grundtvig i hver deres egenart. Alligevel er det ikke problemløst.

Sagen er jo den, at både Luther og Grundtvig fungerer som »kirkefædre« $\mathrm{i}$ den danske folkekirke. Man taler med større autoritet, hvis man kan belægge sine synspunkter med Luther- eller Grundtvigcitater. Derfor skal de jo helst - alle forskelle ufortalt - dybest set være enige. Og derfor kan et spørgsmål som det, om Grundtvigs 
nadversyn nu også var luthersk, føre til en intens diskussion. ${ }^{3}$ Folkekirkens evangelisk-lutherske identitet synes at være truet, hvis ikke Luther og Grundtvig kan siges at være enige. Og da nu Luther har levet før Grundtvig, ender det meget let med, at det er Grundtvig, der måles på Luther, og ikke omvendt. Det kan Grundtvig selvsagt ikke være tjent med, for det kan meget let bevirke, at der i Grundtvigs teologi lukkes af for yderst frugtbare perspektiver, simpelthen fordi de ikke er "problemfrie« $\mathrm{i}$ luthersk forstand.

Derfor kan der være god grund til i langt højere grad at lade Grundtvig tale for sig selv, hvad han også selv helst gjorde uanset den store agtelse for og kærlighed til reformatoren og folkevækkeren Luther, som Grundtvig alle dage vedkendte sig. Ret beset er Grundtvig katolsk i kvalificeret forstand, og det slægtskab, han føler med Luther, går gennemgående altid ud på den katolicitet, som Luther selv ville forsvare med sin reformation. Kirken skulle reformeres til, hvad den havde været, Jesu Kristi sande kirke, der hverken er en stenstue eller et luftkastel (jf. US 5, 285). Grundtvig blev aldrig konfessionel og var dybt mistænksom over for enhver form for konfessionalisme. "Almindelig er Kristi kirke, et bedehus for alle folk « (DDS nr. 285). Det er i den universelle kirkes perspektiv, at Grundtvigs teologi får sin rette profil, hvor ikke mindst indflydelsen fra oldkirken tæller.

Et andet forhold må også tages med i betragtning, nemlig det, at Grundtvig foruden at være kirkelig autoritet også og måske endnu mere er autoritet i spørgsmålet om, hvad dansk identitet eller dansk folkelighed er. Her opfattes han og opfattede vel også sig selv som nærmest en legemliggørelse af dansk folkeånd. Og det kan da bestemt heller ikke nægtes, at historien kun kender ganske få eksempler, om nogen, på mennesker, der havde evner til og fik mulighed for og lejlighed til at præge et samfunds liv på så mange områder, som Grundtvig fik held til at gøre det. Alligevel er Grundtvig ikke tjent med at blive gjort så dansk som muligt, selv om han lagde op til det selv, og da især ikke, når det at være dansk $\mathrm{i}$ meget høj grad defineres som det at være anderledes end alle andre og noget helt for sig selv. Det har næsten været et dogme i grundtvigske kredse, at Søren Kierkegaard af gode grunde kan formidles til hele verden, men Grundtvig kan det ikke, fordi han er så dansk. Sandt nok er han vanskeligere at formidle på grund af sit umiskendelige danske præg, men han kan og bør netop derfor også formidles. 
For Grundtvig stod selv i gæld til mange europæiske åndsstrømninger i sin tid, som han forarbejdede og integrerede i sin egen tankeverden, så at han ikke er til at forstå uden disse relationer. $\mathrm{Og}$ ved at blive forstået $\mathrm{i}$ disse relationer kan Grundtvig selv frugtbargøres i langt flere sammenhænge.

Den lutherske og den danske læsning af Grundtvig kan så forstærke hinanden ved, at den danske evangelisk-lutherske folkekirke af mange opfattes som en væsentlig del af dansk identitet, hvad den givetvis på en besynderlig skævvinklet måde også er.

Grundtvig skal kort sagt befries fra luthersk og dansk omklamring, hvilket på ingen måde må ses som ensbetydende med at skulle opgive lutherske og danske perspektiveringer. De må bare ikke stå alene. $^{4}$

I det følgende vil jeg primært tage mit afsæt i Grundtvigs afhandling »Skal den lutherske Reformation virkelig fortsættes?«, som blev trykt 1830 i J.C. Lindbergs »Maanedsskrift for Christendom og Historie« og udkom i 1863 i en ny udgave. Selv om Grundtvig i forordet til 2. udgave gør en bemærkning om, at han havde et og andet at rette, bl.a. i sit syn på bispeembedet, udgiver han den alligevel på opfordring af yngre venner som et bevis på, at han »i Aarhundredets første Menneske-Alder har kæmpet paa Liv og Død for den Anseelse, Bibel og Lutherdom da aldeles havde tabt hos os, men derved ikke mindst har tilbagevundet « (US 5, 355, herefter kun sidehenvisning).

Endnu et citat må belyse Grundtvigs hjertevarme-kritiske forhold til Luther, selv om Grundtvig om det citerede siger: »Jeg veed meget godt, at saadanne Hjerte-Udgydelser paa Papiret er kun til Latter eller Besvær for de fleste Læsere, og min naturlige Partiskhed for dem, hører ogsaa til den Lutherskhed, jeg aflagger « (327).

Men nu selve citatet. Det følger efter, at Grundtvig i fire punkter, som jeg vender tilbage til, har rettet en meget skarp og skarpsindig kritik mod Luther:

»Medens jeg nu hverken dølger det for mig selv eller for Andre, at saare Faa blandt de Skrift-Kloge er paa min Side, paastaaer jeg dog, at $i$ Grunden er ikke blot Luther selv, men hele den Christne Menighed, med Herren og Aanden, Ordet og Skriften, paa min Side, og Gud lade mig derfor altid være saa vis paa Himmerig (til jeg kommer der) som jeg er paa engang at faae Ret i dette Stykke, hos alle dem, der troende bøie Knæ 
i Jesu Christi Navn, og med frimodige Tunger bekiende, at Han er Herren i Gud Faders Ære! Denne Herre er mit Vidne, at jeg ærer og elsker Morten Luther, som jeg ønsker at æres og elskes af mine Børn, hvad mine Kyndinger veed er ikke saa lidt, og ønsker at kunne see og sige tusind Gange meer til Luthers Undskyldning, end jeg har seet og sagt, skjøndt mine opmærksomme Læsere veed, det er heller ikke saa lidt; men hvor det giælder vor Herres Jesu Christi Tro, hans Kirkes Forsvar, og hans Menigheds Vel, der maa og der vil jeg, selv for Morten Luthers Skyld, ingen Sandhed dølge, og jeg veed, at naar vi mødes i Himmerig, vil han sige: det var i Grunden ikke at takke dig for, thi det var kun din Skyldighed, men du skal dog have Tak derfor af Morten Luthers Aand!« (326-327)

Skriftet »Skal den Lutherske Reformation virkelig fortsættes?« er klart disponeret $i$ tre afsnit ud over en indledning: Reformationens fortsættelse (1) i selve kirken, (2) i forholdet mellem kirke og stat, (3) i forholdet mellem kirke og skole. Ikke mindst det sidste afsnit er vigtigt $i$ vurderingen af Grundtvigs forhold til den lutherske tradition, fordi den i så høj grad først prioriterede den rene lære og sidenhen det rette begreb om kristendommen og således er knyttet mest til skolen.

Grundtvig mener selvfølgelig, at reformationen bør fortsættes inden for alle tre forhold.

Men der kan være grund til lige at hæfte sig ved indledningen (297ff), der er et stort opgør med den selvkloge fornuft, som forstår reformation som ensbetydende med at nedrive alt det gamle for at skabe noget nyt ud af sit eget hoved. Grundtvig vender sig imod den autonome fornuft, der underkender erfaringens betydning, som kort sagt består $\mathrm{i}$, at hvis man vil lære noget, må der være noget at lære. Man kan jo ikke leve af luft.

Derfor afskyr Grundtvig de radikale reformer, som gør en dyd ud af forandringen som sådan, og derfor har han også et kraftigt forbehold over for protestantismen som fænomen.

Men hvad er den lutherske tradition? Det må jo stå klart, når Grundtvigs forhold til den skal beskrives. Og netop det er forbundet med vanskeligheder, da lutherdommen som konfession er et komplekst fænomen. Alligevel må et sådant signalement fors $\emptyset$ ges, hvis vi skal komme videre i vurderingen af Grundtvigs forhold til den luther- 
ske tradition. Følgende træk kan vel siges at være typiske for luthersk tradition:

1. De reformatoriske sola-formler står centralt: Solus Christus, sola fide og sola scriptura. Hvordan disse tre sola-formler sættes i forhold til hinanden, kan der være forskellige meninger om. Men centralt står læren om retfærdigg ørelse ved troen alene.

2. Uanset skriftsyn spiller Bibelens vidnesbyrd en stor rolle for bestemmelsen af, hvad sand kristen tro er. Af samme grund har de hermeneutiske spørgsmål stor vægt, ikke mindst efter fremkomsten af den moderne bibelvidenskab.

3. En stor vægt har endvidere bekendelsesskrifterne, hvad enten man nøjes med de oldkirkelige symboler, Den Augsburgske Bekendelse og Luthers Lille Katekismus, eller man gør brug af hele Konkordiebogen.

4. Som følge heraf spiller forholdet mellem Skriften og bekendelserne en betydelig rolle i den lutherske tradition: Skriften som norma normans, bekendelserne som norma normata. Dermed er der lagt op til, at læreaspektet $\mathrm{i}$ den kristne tro får stor vægt.

5. Det viser sig i den måde, man anvender artikel VII i Den Augsburgske Bekendelse på, nærmere betegnet dens »satis est «. ${ }^{5}$ Hvad er tilstrækkeligt for kirkens enhed?

"Satis est « er i økumeniske samtaler fra luthersk hold blevet tolket enten sådan, at en række lærepunkter skal være opfyldt, for at der kan være tale om kirkelig enhed, eller også sådan, at retfærdiggørelsen ved troen alene som eneste og alt afgørende kriterium for ren evangelieforkyndelse må være den hermeneutiske nøgle i en kritisk vurdering af læreforskelle.

Disse to standpunkter står $\mathrm{i}$ den lutherske tradition klart $\mathrm{i}$ et modsætningsforhold til hinanden ${ }^{6}$, men uanset hvilken side man står på, kommer læreaspektet, den rene lære, til at dominere.

6. Det førte i ortodoksien til en bibelsk dogmatik, hvor de enkelte skriftudsagn kom til at fungere som fundamentale trossandheder, som man byggede dogmatikkens læresystem op på. I nyere tid førte det til, at man koncentrerede sig om at bestemme kristendommens begreb eller dens væsen.

Det er så også disse spørgsmål, der bliver stillet fra luthersk hold i de økumeniske læresamtaler. Og her får Luthers egen teologi selvsagt en særlig autoritet. 
Der kunne sikkert findes flere typiske træk for luthersk tradition, men jeg mener, at disse i hvert fald holder stik. Det betyder, at vi i vurderingen af Grundtvigs forhold til den lutherske tradition primært må beskæftige os med hans vurdering af forholdet mellem kirke og skole.

En uforbeholden positiv vurdering af Luther har Grundtvig på følgende punkter, som man støder på igen og igen:

1. Luthers reformation gik ud på at føre kirken tilbage til dens oprindelige skikkelse.

2. Luther satte troen i centrum - her troen også forstået som lig med den apostolske trosbekendelse - som det bliver tydeligt i Luthers Lille Katekismus.

3. Luther bragte evangeliet og salmesangen tilbage på modersmålet og blev således en folkevækker. ${ }^{7}$

Det er altså som kirkemand, der værner om den oprindelige kirke, og som folkevækker, at Luther får Grundtvigs uforbeholdne ros.

Det gør Luther derimod ikke som teolog, som kirkelærer. Der har Grundtvig et langt mere differentieret og på nogle punkter endda yderst kritisk forhold til Luther for slet ikke at tale om den lutherske tradition.

Men inden jeg uddyber dette nærmere, vil jeg kort referere de første to afsnit i skriftet »Skal den lutherske Reformation fortsættes?«

I kirken skal den lutherske reformation selvsagt fortsættes i den betydning, som også blev tydelig i citatet i note 7 , at kirken skal reformeres, så at den svarer til sit væsen, dvs. sin enhed, apostolicitet, katolicitet og hellighed, sådan som den bekendes i trosbekendelsen. For trosbekendelsen ved dåben som pagtsordet og dermed det pure evangelium er det fælles vilkår for alle kristne til alle tider, og det er nadveren også trods visse forskelle. Den Augsburgske Bekendelses artikel VII er en skjult ledetråd for Grundtvig også i dette skrift som i »Kirkens Gienmæle«. Som en slags programerklæring kan Grundtvig sige:

»Vi vil tjene vor Herre Jesus Christus, som er undfanget af den Hellig-Aand og født af Jomfru Maria, og vi vil tjene Ham som vore christne Fædre, som Morten Luther og Ansgar, som Augustinus og Irenaus, som Paulus og Johannes, kort sagt, 
som den gamle Discipel, der skal ikke døe, men synge gladelig: kom, Herre Jesu! naar Skyerne skinne af Hans Faders Herlighed, og Han kommer øiensynlig igien at dømme Levende og Døde!« (286f)

Selvsagt er reformationen også et opgør, en »Udfeielse«, på den ene side af ærkekatolikkernes »Steen-Stue« af en kirke og på den anden side af protestanternes »Luft-Castel« af et kirkebegreb, konstrueret af fornuften. For kirken er en menighed af levende stene. Fornuft som dømmekraft er i sin orden og kan ikke undværes. Men skaber den luftkasteller, må den forkastes. Grundtvig undsiger den spekulative teologi. Han afviser et kirkesyn, der defineres ud fra et lærebegreb om kirken, og som glemmer, at kirken er en historisk realitet.

Det er da også karakteristisk for de to følgende afsnit, at Grundtvig fortæller kirkehistorie for at pejle sig ind på reformationens mulige fortsættelse i kirkens forhold til staten og til skolen.

Også i forholdet til staten gælder det, at reformationen må fortsætte i selvsamme betydning, nemlig at bringe kirken tilbage $» t i l$ sin oprindelige Beskaffenhed i alle henseender« (296).

Og da kirken oprindelig var skilt fra staten, skal kirken igen skilles fra staten. Det skal den på grund af samvittighedsfriheden og for at undgå skinkristne.

Romerkirken gjorde staten til en kirkelig indretning. Reformatorerne undgik at gøre kirken til en statskirke i gammel-romersk, dvs. konstantinsk forstand. Den blev en apostolisk kirke i forbund med staten (jf. 301). Men i længden blev de enkelte reformatoriske kirker til protestantiske nationalkirker, hvor fyrsten igen hersker over samvittighederne.

I den nuværende situation ser Grundtvig ingen anden udvej end, at de gammeldags kristne, som han selv regner sig til, får lov til at gå ud af kirken. Som en mere moderat løsning foreslår han her som siden sognebåndsløsning og præstefrihed samt en trosfrihed inden for statskirkens rammer, der giver mulighed for, at forskellige meninger brydes. Faste bestemmelser skal der kun være i forbindelse med dåb og konfirmation, altså når det drejer sig om de kristne grundvilkår.

Her løber Grundtvig ind i en selvmodsigelse, men den har han for så vidt tilfælles med den lutherske tradition. På den ene side ønsker han reformation af kirken til dens enhed, apostolicitet og katolicitet eller universalitet. På den anden side lægger han selv op til en ny 
splittelse. Det dilemma stod allerede reformatorerne i. Ganske vist udtrykker hans ideer om sognebåndsløsning og præstefrihed en vilje til at bevare sammenholdet $\mathrm{i}$ kirken, men på præmisserne af en forståelse af trosfriheden, der er mere i overensstemmelse med modernitetens og dermed protestantismens frihedsforståelse, hvor det enkelte menneskes frihed sættes over hensynet til fællesskabet. For det er jo den enkelte troende, der frit skal kunne afgøre, hvilken menighed hun eller han vil tilhøre, og det er den enkelte præst, der frit skal kunne afgøre, hvem han vil tage til alters og ind i sin menighed.

Også med et andet af sine anliggender kommer Grundtvig i et spændingsforhold, nemlig den venlige vekselvirkning mellem det kristelige og det folkelige, der forudsætter et kirkesyn, som Grundtvig fx gør gældende i »Christenhedens Syvstjerne«, Kristi kirke som bestående af folkemenigheder. Man kan svært forestille sig, at folkemenigheden kan fastholdes som en virkelighed samtidig med retten til sognebåndsløsning og præstefrihed, ${ }^{8}$ medmindre det er det folkelige, altså det danske, som binder de enkelte valgmenigheder sammen til folkemenighed. Men så er grundlaget for kirken unægtelig blevet et andet end det, som Grundtvig ønskede kirken reformeret tilbage til.

Dermed kommer vi til det tredie afsnit omhandlende den lutherske reformation i forholdet mellem kirke og skole. ${ }^{9}$

Grundtvig lægger ud med en polemik imod nutidige protestantiske teologers måde at benytte Skriften på. De nytestamentlige skrifter blev samlet for at værne om den rette forståelse af den apostolske tro. Men dermed lagdes grunden til det sidenhen så farlige misforhold mellem kirken og skolen, eller mellem troen og teologien.

Når Bogen skal dømme om, hvad den sande kristne tro er, bliver det de boglærde, der får dommerhvervet, for Bogen selv er stum. Grundtvig modstiller her Alexandria og Rom, hvor Rom for en gangs skyld får en positiv vurdering. Akademiet i Alexandria repræsenterer i Grundtvigs $\varnothing j n e$ den græske skolemester-visdom. Konstantinopels fald bliver anledning til, at denne visdom forplantes til vesten og sammen med videnskabernes genopblomstring dér kommer til at danne baggrund for reformationen. Og Grundtvig vil på ingen måde benægte den betydning, det havde, at Bibelen blev genopdaget som oplysningsbog og »Værne-Skrift« mod opdigtelser.

Men desuagtet kritiserer Grundtvig Luther for følgende punkter (jf. 326): 
a. at Luther afviser den mundtlige tradition generelt uden at friholde trosbekendelsen og de to sakramenters indstiftelsesord;

b. at Luther fastholder sola-scriptura-princippet;

c. at Luther »oversaae Kirke-Historiens Vidnesbyrd om det Oprindelige i Kirken, naar han ikke fandt det stadfæstet i Bibelen; «

d. at Den Augsburgske Bekendelses »Udvikling af Saliggiørelsens Orden « skal antages som trosartikler af alle sande kristne.

Jeg vil lade det ligge, om Grundtvigs kritik af Luther er retfærdig, men den er i hvert fald en klar undsigelse af væsentlige sider af den lutherske tradition.

Det vil jeg uddybe ved hjælp af de punkter, som Grundtvig selv opregner (jf. 328ff):

a. Grundtvig tilkender den mundtlige trosbekendelse ved dåben en særstilling i den mundtlige apostolske tradition. Dette »Kirke-Ord« er »som Menighedens eenstemmige Vidnesbyrd om sin Tro det gyldigste historiske Vidnesbyrd, der kan gives om, hvad alle Christne fra Begyndelsen af har troet.« Hvis ikke man skulle kunne lære en menigheds tro at kende ved hjælp af dens trosbekendelse, kan man slet ikke lære den at kende. Dette "mageløse mundtlige Vidnesbyrd « må på ingen måde sammenblandes »med alle løse Rygter om den oprindelige Christendom « (330).

Betegnende sammenligner Grundtvig trosbekendelsen med en ed, der fastlægger grundforholdet mellem konge og folk, og som enhver konge skulle aflægge ved sin tronbestigelse. Denne ed er et bedre historisk vidnesbyrd om et lands grundforfatning end en hvilken som helst ældgammel rigskrønike, der kan være behæftet med afskrivningsfejl. Og det er eden, der binder kongen, ikke krøniken. Sammenligningen viser, at Grundtvig også her klart forstår trosbekendelsen som pagtsordet, ved hvilket Gud i dåben binder sig til et bestemt menneske, og ikke som en lærebekendelse, som ortodoksien gjorde det. Det markeres tydeligt i punkt b. som indledes såre karakteristisk således: „At det ikke er ved BibelLaesning, men ved Daaben, Man optages i vort Kirke-Samfund, det er en Kiends-Gierning « (331). Trosbekendelsen er trosreglen og grundloven, der i uløselig enhed med dåben sætter skel mellem kirke og verden. Dåben alene som handling gør det ikke, heller ikke ledsaget af det trinitariske døbeord, for det får kun sin kristne præcision i trosbekendelsen. Om Grundtvig har ret i den påstand, kan diskuteres. Bibelen sætter endnu mindre dette skel, for at tro på 
Bibelen er ikke uden videre ensbetydende med at tro på Jesus Kristus. Derimod peger Bibelen selv på troen, dåben og bekendelsen som salighedsvilkår.

c. Som trosregel og grundlov for hele den kristne menighed må trosbekendelsen ligeledes være tolkningsregel for Skriftens udlægning, hvilket også de skriftkloge medlemmer af menigheden må bøje sig for. Her bliver den ellers så frihedselskende og forsvarende Grundtvig yderst skarp i mælet. Hvis de skriftkloge vil »bestride Menighedens Tro med deres Lærdom, da skulde de udelukkes, som aabenbare Kiattere« (333). Bibelen er kun en bog, hvor fortræffelig den så end må være, og den kan ikke skænke syndernes forladelse og evigt liv. Grundtvig er ude efter den tendens, der alle dage har været stærk i den lutherske tradition, at gøre kirken til en læreanstalt, hvilket efter hans mening er ensbetydende med at underkende menigheden eller det almindelige præstedømme. Hvis menigheden ikke kan holde sig til trosbekendelsens enkle måde at udtrykke kristendommens indhold på, så er lægfolket på nåde og unåde udleveret til de skriftkloge, medmindre de går hen og læser græsk, hvilket selvsagt er en absurd tanke. Skulle det efter Grundtvigs mening nærmest utænkelige tilfælde indtræffe, at trosbekendelsen ville komme i modsætning til Bibelen, så må vi "forandre vore Tanker om Bibelen, eller dog om Geistlighedens Redelighed og Nøiagtighed ved Bogens Afskrift og Overantvordelse « (334). Skriftklogskaben må aldrig komme til at beherske troen, men tværtimod lade sig beherske af troen, tro her forstået lig med trosbekendelsen som Guds pagtsord ved dåben og kristendommens trosregel og grundlov. Efter Grundtvigs mening fulgte Luther selv denne regel. "Men kunde man da ikke sige, « spørger Grundtvig, "at siden Luther, ved at begynde med Skriften, kom til det Samme, som naar man begynder med Ordet i Kirken, er den hele Tvist om: hvor Man helst skal begynde, mest kun en tom Ord-Strid, meer til Skade end til Gavn?« (335) Det afviser Grundtvig, »thi, blandt andet har den sidste Tid klarlig viist, hvilken mærkelig Forskiel det giør, om Man i Theologien begynder fra den rette eller fra den vrange Side« (ibid.). Det lutherske skriftprincip måtte kaste menigheden ud i tvivl og modløshed, når der blev sat spørgsmålstegn ved og krævet beviser for Skriftens ægthed og guddommelighed, sikkerhed og klarhed. Det ville ikke have været tilfældet, hvis der var blevet tilkendt trosbekendelsen og nadverindstiftelsens ord autoritet 
som fuldgyldigt vidnesbyrd om den oprindelige kristendom uafhængig af Skriften.

d. Det fører Grundtvig til det vel nok mest afgørende brud med lutherdommen. Han opgiver skriftprincippet, "sola scriptura" som formalprincip: »At Bibelen, desuden, hverken oprindelig har været, eller, efter sin Beskaffenhed, kan være Troes-Regel i den Christne Kirke« (328). Det Gamle Testamente kan af gode grunde ikke have været trosregel for de første kristne, og Ny Testamente var ikke blevet til endnu. Troen var altså forud for Skriften. Tro på Bibelen kunne da heller ikke være et dåbsvilkår, rent bortset fra, at det er umuligt at tro på en bog. Det fremgår også tydeligt af Ny Testamente selv, at det forudsætter den kristne tro hos sine læsere.

Grundtvig har her vist det fornødne mod til at tage konsekvenserne af den historiske omgang med de bibelske skrifter både $\mathrm{i}$ undersøgelsen af den gammeltestamentlige og den nytestamentlige kanons tilblivelse og $\mathrm{i}$ fortolkningen af skrifternes indhold. Det er påstanden om Bibelen som grundlag for den kristne tro eller som troens fundament, der fører til de ulidelige diskussioner, om Bibelen kan tage fejl eller alligevel har ret. Grundtvig tager fuldstændig afslappet den historiske bibelkritiks resultater til efterretning. ${ }^{10} \mathrm{Og}$ samtidig kan han tilkende Bibelen størst mulig autoritet som den kristne oplysningsbog, „den ypperste Bog i Verden. " kan ikke frikende Grundtvig for selv $i$ sin opfattelse af den apostolske trosbekendelse at have en snært af fundamentalisme og historisme, der ret beset jo er to alen af samme stykke. For trosbekendelsens vedkommende $\varnothing$ nsker han nemlig at fastholde beviselig ægthed og tekstens bogstavelige sikkerhed. Men ved at forstå trosbekendelsen primært som Guds pagtsord i Kristus ved dåben og dermed som udtryk for den opstandne Herres nærvær som Guds levende ord, peger han på det afgørende: Kristus som Skriftens herre og midte og troen på ham som fortolkningsnøgle til Skriften. På det punkt er Grundtvig så i dyb overensstemmelse med Luther. Dette standpunkt står og falder heller ikke med trosbekendelsens beviselige ægthed og tekstens bogstavelige sikkerhed, for indholdet står klart.

I forhold til protestantismen er Grundtvig både mere radikal og samtidig konservativ. Ved at opgive Skriften som trosregel og trosfundament varetog han egentlig på sin tid i anerkendelse af den moderne bibelkritiks vilkår det anliggende, som reformationen netop 
gjorde gældende med »Skriften alene«. Det skulle jo forsvare »Kristus alene « og »troen alene«, Kristi prioritet forud for og over alle menneskelige overleveringer. Det samme gør Grundtvig med den særstilling, han tilkender trosbekendelsen som Jesu mundsord.

e. Trosbekendelsens status som den kristne menigheds trosregel og grundlov får selvsagt konsekvenser for, hvem man i kirken må anse som katter og derfor udelukke. Her står Grundtvig frem som en såre radikal $\emptyset$ kumeniker med en meget inklusiv kirkeforståelse samtidig med, at han gør gældende, »At der nu bør drages en skarpere Grændse-Linie end nogensinde mellem hvad alle Christne skal troe og bekiende, og hvad der maa overlades til Aandens og hver enkelt Christens fri Raadighed « (328). Med rette ser Grundtvig en skarp grænsedragning som uopgivelig betingelse for en stor indre rummelighed i kirken. Grundtvig har et meget enkelt kriterium for hæresi: Fornægtelse eller åbenbar modsigelse af trosbekendelsen. ${ }^{12}$ Det fører til nogle overraskende konsekvenser. Der er ikke grund til at antage, at Grundtvig nærede stor sympati for Arius. Ikke desto mindre kritiserer han kirkemødet i Nicæa for,

»at Man i det Mindste brugde en vrang Fremgangs-Maade; thi enten skulde det være beviist, at Arius havde brudt sin Daabs-Pagt, eller han maatte ikke udelukkes af Kirken. Man udelukde ham imidlertid paa Grund af at han ei vilde bruge et vist Udtryk om Herren, som hverken forekom i Troes-Bekiendelsen, eller engang fandtes i Skriften, og hermed var det første offenlige Skridt gjort over Grændsen ind i det Grændseløse; thi naar man kan blive Kiætter, skjøndt Man for menneskelige Øine har holdt sin DaabsPagt, da er det omtrent ligegyldigt, enten Man dømmes efter de fleste Stemmer i en Bispe-Forsamling, eller efter den for Øieblikket herskende Skrift-Fortolkning, thi Fremgangs-Maaden er i begge Tilfælde lige vilkaarlig, og uforsvarlig« (341f)

Jeg har medtaget dette lange citat, fordi Grundtvig for mig at se her rammer plet. Kirkehistorien er fyldt med eksempler, der viser rigtigheden af hans iagttagelse. Grundtvig skelner klart og med rette imellem trosliv og troslære. Og til forskel fra ikke blot den lutherske, men også fra de fleste andre konfessionelle traditioner placerer han kætterbegrebet ikke i troslæren, men i troslivet. En åbenbar modsigelse eller undsigelse af den apostolske trosbekendelse eller et af dens 
led er at bryde sin dåbspagt, med andre ord at skære livsnerven over. Dermed har man selv sat sig uden for den kristne menighed og gjort sig selv til kætter. Dette kriterium på hæresi er forståeligt for enhver, gejstlig som læg. Men så snart man vil gøre Skriften til kriterium for, hvad der er ret tro eller hæresi, er den kristne menighed udleveret til eksegeternes pavedømme. Lige så lidt kan Den Augsburgske Bekendelse eller nogen anden "symbolisk Bog « kræve almengyldighed i den kristne kirke som »Lare-Forskrift«, for der har eksisteret sand kristendom i kirken før deres tilblivelse, og »endnu langt mindre....som Troes-Bekiendelse, selv om den var inspireret« (343). I modsat fald ville kirken være udleveret det konfessionelle pavedømme, hvadenten det udøves af bispekollegier eller af teologiske fakulteter.

Ud fra sit enkle, men klare kætterbegreb forlanger Grundtvig derfor, at man på den ene side skarpt adskiller sig fra dem, der forkaster dåbspagten, og på den anden side ophører med »at paastaae Grund-Forskiellighed fra dem, der have Daabs-Pagt tilfælles med os« (ibid.). ${ }^{13}$ Dette er i åbenbar modsætning til den lutherske tradition, sådan som den blev karakteriseret ovenfor. Grundtvig bryder med et konfessionelt kirkesyn. Han er klart økumenisk både $\mathrm{i}$ forhold til andre kirkesamfund såvel som i forhold til sin egen lutherske kirke. Lige så skarpt, som hæresiet er defineret, lige så rummeligt bliver der så i kirken. Der er intet $\mathrm{i}$ vejen for en pluralitet af læremeninger, så længe der holdes fast ved dåbspagten. Det må vel også gælde en uenighed i dåbssynet, så længe blot selve dåbspagten ikke er blevet undsagt.

Hvor stor en rummelighed Grundtvig kan tænke sig i kirken, bliver tydeligt i det følgende. Han forestiller sig muligheden af uenighed inden for kirken om nadverens indstiftelsesord, om Herrens bøn, Herrens velsignelse, Herrens dag, Skriften og det kirkelige læreembede, når blot ikke dåbspagten er brudt (jf. 344). Men det kan ikke nægtes, at der går skår i rummeligheden, når man ser på, hvordan Grundtvig konkret forestiller sig at skulle leve med denne uenighed i kirken. Han finder nemlig »i den Christne Kirke en dobbelt Forbindelse, som ikke blot betegnes ved, men skabes af de to Sacramenter eller Naade-Midler: Daaben og Nadveren, men som i Troes-Bekiendelsen udtrykkes ved Ordene: den hellige almindelige Kirke, og de Helliges Samfund (Fællesskab). I Kirken optages vi ved Daaben, under Troens Betingelse, og i de Helliges Samfund indlem- 
mes vi, staaende i Daabs-Pagten, ved Nadveren« (343f). Disse to forbindelser må hverken forveksles eller sammenblandes. Man vokser så at sige fra den ene ind $\mathrm{i}$ den anden. Som nævnt godkender Grundtvig grundlæggende uenigheder i kirken, men de nævnte afvigelser må efter hans mening føre til, at man ikke har nadverfællesskab med dem, der forfægter dem. De hører altså ikke med i den anden forbindelse, de helliges samfund. Grundtvig kalder dem for "Sarsindet« og tilsteder dem at danne »en kirkelig Forbindelse med Lige-Sindede«, en »Vinkel-Kirke« (344), men udelukkes fra kirken må de ikke, så længe de holder fast ved dåbspagten, selv om de på deres side erklærer de andre for at være kættere. Der er helt klart et stykke kirketugt i disse ekklesiologiske overvejelser, ganske vist i positiv retning. ${ }^{14}$ Udelukkelsen fra nadverfællesskabet skal få de særsindede til at komme på bedre tanker, så "Daaben hos dem kan træde i Kraft og bære Saligheds-Frugter« (ibid.). Så længe de holder fast ved dåbspagten, gælder det om at holde dem fast. Det er et aldeles positivt $\varnothing$ kumenisk standpunkt, men at benytte udelukkelsen fra nadverfællesskabet i kirketugtsformål forekommer dybt problematisk, selv om Grundtvig bestemt ikke er den første til at benytte dette middel. Denne praksis kan friste til en skelnen mellem første klasses og anden klasses kristne, og da bliver nadveren stik imod sit væsen en eksklusiv handling. Og Grundtvig synes helt at glemme, at nadverfællesskabet fra gammel tid var bekræftelse af kirkefællesskab. At blive udelukket fra nadverfællesskabet på grund af divergerende tro var ensbetydende med udelukkelse fra kirken som kætter. En anden ting var at blive udelukket fra nadverfællesskabet på grund af en gudløs adfærd, man ikke ville angre. Men det er der jo ikke tale om hos Grundtvig.

Det interessante ved Grundtvigs overvejelser er, at han klart ser, at den for troen nødvendige frihed til meningsdannelse, som også er i overensstemmelse med nutidens krav om meningsfrihed, må føre til en pluralitet af trosmeninger. Her er han på linie med protestantismen, men i klar modsætning til dens tendens til stadig nye kirkesplittelser og dannelse af nye kirkesamfund. Grundtvig giver sit bud på, hvordan det er muligt at eksistere $i$ et pluralistisk kirkesamfund uden kirkesplittelse og uden tab af det grundlæggende. At dette bud ikke er holdbart, gør ikke hans anliggende mindre berettiget. At lade det ligge er ensbetydende med at overlade afgørelsen af eventuelle lære- 
sager til tilfældigheder og dermed vilkårlighed. Det så Grundtvig også klart.

f. I dette afsluttende punkt drager Grundtvig så konklusionen af de hidtidige overvejelser med henblik på det rette forhold mellem kirke og skole, som han ligestiller med forholdet mellem kristendom og teologi, »thi det er aabenbar givet i Forholdet mellem Kirke-Ordet og den Hellige Skrift, af hvilke Hiint udtrykker det Nødvendige, og denne betegner det Fri i vort christne Samfund « (350).

Ligesom den enfoldigste kristne er teologen forpligtet på dåbspagten, men ellers står han frit "paa eget Ansvar for Herren og sine Medstuderende, at behandle Kirke-Bogen, og afhandle Spørgsmaalet om Christendommens videnskabelige Side efter Godtbefindende« (ibid.). Den frihed tilkommer enhver borger i Guds rige af hensyn til helhedens vel, for kun sådan kan sund lærdom bevares, oplysning fremmes og bære frugt $i$ en bedre forståelse af Bibelen. Denne frihed må på ingen måde indskrænkes ved at binde teologerne »til andre Symbolske Bøger, end Bibelens « (ibid.) Grundtvig ønsker at fastholde en forbindelse mellem frihed og nødvendighed, men indrømmer, at det er en svær nød at knække for nutidens teologer. Enten insisterer man på det ene eller på det andet. Men nødvendigheden er begrundet i, at »Kirken er nemlig aabenbar ikke til for Skolens, men for Salighedens Skyld«, og friheden er begrundet i, »at Skolen er ikke blot til for Kirkens, men tillige for Oplysningens Skyld«, og det ville være »til Kirkens Skam og Skade, naar Oplysnings-Værket gaaer i Staa« (351).

Hvad Grundtvig altså forestiller sig, er en teologi, der er befriet fra konfessionelle bindinger, men som alligevel er kirkelig og samtidig på ingen måde uforpligtet på oplysning i almindelighed. Det er et $\emptyset$ kumenisk og samtidig i bedste forstand oplyst teologibegreb. Er at forfægte det at blæse og samtidig have mel i munden, altså kort sagt en umulighed? Inden for kirken fastholdt Grundtvig muligheden af at udelukke en teolog som kætter, der åbenlyst undsagde sig dåbspagten. Men ellers skulle teologen stå frit også inden for kirken, ganske vist med den risiko, at Grundtvig ville nægte ham som særsindet adgang til nadverbordet. Hvis teologen var ansat $i$ en statskirkelig stilling med visse forpligtelser, som det var tilfældet dengang for universitetsprofessorernes vedkommende, måtte han efter Grundtvigs mening opfylde forpligtelserne eller træde ud af stillingen. Grundtvig 
fastholdt derfor kravet fra »Kirkens Gienmæle« til professor H.N. Clausen om at nedlægge sit præstelærerembede. ${ }^{15}$

Set med vor tids $\varnothing$ jne og på vor tids vilkår kan Grundtvigs standpunkt ikke uden videre fastholdes. Der må i det mindste skelnes imellem den teologi, der drives indenfor i kirken, og den teologi, der drives udenfor, nemlig i skolen eller ved universitetet. Grundtvig selv vidste jo også at skelne imellem kirkeskole og skole. Inden for kirken kan teologiens forpligtelse på dåbspagten selvsagt fastholdes, men udenfor ikke. Den nødvendighed kan ikke gøres gældende for de teologiske fakulteter ved universiteterne, $i$ hvert fald ikke som en ydre nødvendighed, som det kan pålægges fakulteterne at skulle bøje sig for. Ikke desto mindre peger Grundtvigs overvejelser på et stående problem inden for protestantisk teologi siden oplysningstiden, da teologien for alvor begyndte at differentiere sig $\mathrm{i}$ de forskellige historiske og systematiske discipliner. Dette problem er teologiens enhed. Differentieringen har uden tvivl gavnet den videnskabelige frihed, men til gengæld har man til tider haft svært ved at lade sig overbevise om, at teologien er et sammenhængende fagområde, når man ser bort fra traditionelle grunde. Teologiens enhed bevares kun, når man også på skolens præmisser er opmærksom på den af Grundtvig påpegede forbindelse mellem nødvendighed og frihed i det teologiske arbejde. Nødvendigheden kan her ganske vist ikke accepteres som en ydre. Den erkendes som en indre nødvendighed i det teologiske stof, der selv gør sig gældende i og med, at den fremdrages i frihed.

Den frihed for teologien, som Grundtvig selv kæmpede for, kan passende gøres gældende for enhver omgang med Grundtvig selv, hvad enten den er teologisk, historisk eller litterær, så at han befries fra omklamringer af enhver art.

\section{Noter}

1 Denne artikel er en bearbejdet og udvidet udgave af manuskriptet til mit foredrag ved Grundtvig-Selskabets 50 års jubilæumskonference, august 1997.

2 Theodor Jørgensen: Grundtvig und Luther - welche Bedeutung hatte Luther für Grundtvig? s. 97-108. I: "Luther im Widerstreit der 
Geschichte«, Veröffentlichungen der Luther-Akademie Ratzeburg, Bd. 20, 3, Hg. Joachim Heulbach. Erlangen 1993.

3 Se Chr. Thodberg, Grundtvig und Luther. Das Abendmahl in ökumenischer Sicht. I Kerygma und Dogma XXX 1984, s. 19-41. Chr. Thodberg, Syn og Sang, Poesi og Teologi hos Grundtvig. København 1989, s. 296ff; Chr. Thodberg, Om Grundtvigs nadversyn, I: Præsteforeningens Blad 1987/41, s. 769ff.; Regin Prenter: Gjorde Grundtvig op med den lutherske nadverlare? I: Præsteforeningens Blad 1987/9, s. 153ff; Leif Kallesen, Mere om Grundtvigs nadversyn I: Præsteforeningens Blad 1987/41, s. 776ff; se også Leif Kallesen, Nadverelementerne og billedsynet I: For sammenhangens skyld, ord og motiver i Grundtvigs salmer og pradikener, redigeret af Chr. Thodberg, Århus 1977, s. $186 \mathrm{ff}$.

4 For mig at se er denne konferences program et indicium på, hvordan Grundtvig-Selskabet siden sin start for 50 år siden har været medvirkende til at løse op for denne lutherske og danske omklamring. Det er en udvikling, der forhåbentlig må fortsætte. At den nyeste indføring $\mathrm{i}$ Grundtvigs liv og gerning er skrevet af en anglikaner, betragter jeg som en klar gevinst, jf. A.M. Allchin: N.F.S. Grundtvig. An Introduction to his Life and Work. With an Afterword by Nicholas Lossky. Århus 1997.

5 "Ligeledes lærer de, at der bestandig vil være og forblive én hellig kirke. Men kirken er de helliges forsamling, i hvilken evangeliet læres ret og sakramenterne forvaltes ret.

Og til kirkens sande énhed er det tilstrækkeligt, at man stemmer overens om evangeliets lære og sakramenternes forvaltning. Derimod er det ikke nødvendigt, at man overalt har de samme menneskelige overleveringer eller kirkeskikke eller ceremonier, som også Paulus siger: "Een tro, een dåb, een Gud og alles Fader «. (Efes. 4,5)« Den danske Folkekirkes Bekendelsesskrifter samt Dr. Martin Luthers store Katekismus i oversattelse, med indledning og noter v. Johs. Feveile og Max W. Olsen, København 1955, s. 53 .

Efter den latinske tekst kan både oversættes »at evangeliet forkyndes rent« og » ... at evangeliet læres (!) rent«.

6 Falleserklaringen om retfardiggфrelseslaren, revideret udgave 1997, Udarbejdet af Det lutherske Verdensforbund og Det pavelige Råd til fremme af kristen Enhed. Udgivet af Det Mellemkirkelige Råd. Esbjerg 1997. 
7 Jf US 5, s. 285f: »Herren har nemlig bygget sin Kirke ikke af døde, men af levende Stene, og lider ingen Tilbygninger, som altid bliver RøverKuler; men desuagtet var dog hans Kirke i Tidens Løb blevet hartad steendød, da den Gnist af Liv, der end var tilbage, misbrugdes til at giøre Røgelse paa Afguds-Altre. Da opstod Morten Luther, som man aandelig vaagner op af Dvale, opstaaer fra de Døde, og lod Christus lyse for sig, og fik af Ham det store Ærende, han saa trolig røgtede, i Herrens Navn at vække de Sovende, opvække de Døde, og lære dem at see Lys i Herrens Lys, og leve af det Brød, som kom ned fra Himmelen, og at tage Salighedens Kalk af Hans Haand, hos hvem Livets Kilde er. En saadan Reformation, det er Fornyelse, der er som Liv af Død, det er aabenbar den Eneste, der kan finde Sted i Christi Kirke, og at en Saadan timedes den ved Morten Luther, det er saa vist, som at i ham begyndte Apostlerne igien at tale Guds underlige Ting med Folkenes Tunger, med hans Psalmer begyndte Menighederne paa $\mathrm{Ny}$ at love Herren paa det Tungemaal, som de var fødte, og kunde udtrykke sig levende i, ved ham blev den Hellige Skrift igien den christelige Læse-Bog for Herrens Folk, hvortil den var bestemt, og fra hans Dage begyndte klarlig de Troende, som fulgte ham, et nyt Levnets-Løb, vel ikke saa reent og kraftigt som det ældgamle, men dog kiendelig renset, virksomt, elskeligt og frugtbart paa christelig Oplysning.«

Præstefriheden blev som bekendt aldrig gennemført.

Jf. til det følgende US 5, s. 318ff.

10

"..vi frafalde naturligviis, som Feiltagelser, alle de Paastande vi kun i vor Forblindelse have ladt os forlede til at giøre, saavel om Inspirationen af hvert Ord i det Gamle og Ny Testamentes bibelske Kirke-Historie, som om alle de bibelske Bøgers beviislige Ægthed, om Textens bogstavelige Sikkerhed, og Skriftens umiddelbare Klarhed, og undersøge kun rolig Spørgsmaalene desangaaende, til Oplysning for Menigheden, der ligesaa rolig kan afvente Udfaldet, da hverken Liv eller Vext staaer længer, som hidtil, paa Spil, naar der strides om Skriften« (US 5, s. 339).

11 US 5, s. 347, jf. hele sammenhængen $345 \mathrm{ff}$.

12 US 5, s. 341: "..thi naar et Samfund virkelig har en Tro, hvorpaa Det bygger sit Saligheds-Haab, og er arligt, da kan det aabenbar ikke vedkiende sig noget Medlem, der enten fornægter eller dog aabenbar modsiger Samfundets Tro..« 
${ }^{13}$ Grundtvig ville næppe i dag have sagt nej til Porvoo-erklæringen om kirkefællesskab mellem de lutherske kirker i Norden og de baltiske lande og den anglikanske kirke, som vel nok flertallet af grundtvigianerne gjorde det.

14 I forbindelse med den forskel, Grundtvig sætter mellem kirken og de helliges samfund, henviser han da også til »den Forskiel, der altid har været beregnet ved den lille og den store Band, og som ligger i Sagens Natur« (US 5, s. 344).

15 Jf. fodnoten US 5, s. 351. 